\title{
森林域からの流出窒素ポテンシャルに関する 広域的評価の試み：矢作川流域における事例
}

\author{
伊藤江利子 1) 小野賢二 2) 清水 貴範 3) \\ 竹中千里 4) 服部 重昭 4) 荒木 誠 1)
}

\author{
1)森林総合研究所 \\ (テ305-8687 つくば市松の里1) \\ 2) 森林総合研究所東北支所 \\ ( T020-0123 岩手県盛岡市下槈川字鍋屋敷92-25) \\ 3) 森林総合研究所九州支所 \\ ( =860-0862 熊本県熊本市黒髪4丁目11-16) \\ 4) 名古屋大学大学院生命農学研究科 \\ ( ₹464-8601 名古屋市千種区不老町)
}

森林の適切な管理を行うためには，森林域からの窒素負荷を簡便かつ広域的に推定する手法が必要である，そのた め, 矢作川流域の森林域 $1,340 \mathrm{~km}^{2}$ を対象とし, 森林土壤から溪流水を通じて流出する窒素負荷の可能性を, 以下の3 つの過程で推定した．1）森林表層鉱質土壤 $(0-5 \mathrm{~cm})$ の窒素無機化・硝化速度を室内培養法で測定する．2）立地環 境特性から流出窒素ポテンシャル（培養期間中の硝酸態窒素生成量を面積あたりに換算 $; \mathrm{Mg} \mathrm{N} \cdot \mathrm{km}^{-2}$ ) を予測する多 変量回帰モデルを作成する. 3) モデルに既存のGISデータを入力して, 流域全体の流出窒素ポテンシャルを推定する. さらに，広域的な水質予測を行うため，簡易蒸発散量推定式を用いたGISモデルによって年流出量 $\left(\mathrm{mm} \cdot \mathrm{yr}^{-1}\right)$ を推 定した。実測流入量と比較して, 流出量推定モデルの精度を検証した. 最後に, 広域的な水質予測の指標としての溪 流水窒素濃度ポテンシャル（流出窒素ポテンシャル/年流出量 $; \mathrm{mg} \mathrm{N} \cdot \mathrm{L}^{-1}$ ) を推定した. 既往の渓流水窒素濃度測定 值と比較して，本稿で試みた手法が広域的な傾向を再現できることを確認した.

キーワード：窒素流出, 河川水質, 広域スケール, GISモデル

\section{I 、はじめに}

森林は流域の上流に位置し，下流に対して清浄な 水を安定的に供給する機能を担っている。森林から 流出する渓流水の水質は一般に降水の水質とは異なっ ており, 降水が森林生態系を通過する間に起こる水 質の変化は, 森林の地下部, すなわち森林土壤 - 風 化層・基岩に負うところが大きい（有光ら，1988； 加藤ら，1995). そこで, 森林生態系におけるこの ような水系網を通じた物質の移動が卓越する系で は, 系内の森林の立地条件を考慮したうえで, 流域 的な視点に立った土地利用管理が求められている (木村ら，2006)。そのためには森林と下流域の農 地・都市域・水域等との空間的な位置関係を視野に 入れて, 森林が有する水質形成機能を広域で評価す る必要がある。
主要な環境影響物質のひとつである窒素は, 無機 態窒素 (多くは硝酸態窒素) として溪流水・地下水 を通じて森林生態系から流出する (Campbell et al., 2004). 窒素負荷流出に関わる影響要因を広域的に 解析する試みはこれまでにも行われてきた。それら には, 降雨量 ·流量と水質濃度 ·負荷量との応答関 係から降雨時の窒素負荷流出に影響を及ぼす水文因 子を解析した例（高橋ら，2000）や農地における施 肥が水質に及ぼす影響を広域で簡便に推定した例 （Geng et al., 1996）がある. また, 森林生態系の窒 素動態を対象とした試みとしては, 窒素負荷流出に 関わる複雑なプロセスを生態系モデルによって再現 して窒素流出を予測した例（Band et al., 2001）や, 土壤中の炭素や窒素の動態が窒素流出や渓流水質に 及ぼす影響のスケール依存性を解析した例（Grant, 
2001）がある。しかしながら，流域管理を目的とし た実用的な視点から森林域からの窒素負荷流出の可 能性を簡便かつ広域的に推定する試みはほとんどな されていない.

本稿では, 上〜中流部に森林, 中〜下流部に農耕 地および都市という典型的な土地利用パターンを示 し, 日本の一級河川の平均的な流域面積を有する矢 作川流域を対象として, 以下のような検討を行った。 まず，森林が有する水質形成機能を広域で評価する ため, 森林域からの流出窒素ポテンシャルを簡便か つ沉用的に評価する手法について提案し，これを適 用した。ここでは, 森林表層土壤 $(0-5 \mathrm{~cm})$ を室内 培養法において標準的 (平井ら，2006）かつ微生物 の活動に好適な温度·水分条件 (土壤養分測定法委 員会編，1987）で培養したときに生成した硝酸態窒 素量（森林面積あたりに換算）を，硝酸態窒素の潜 在的最大生成量の目安となる流出窒素ポテンシャル $\left(\mathrm{Mg} \mathrm{N} \cdot \mathrm{km}^{-2}\right)$ として定義した.

さらに，流域スケールでの水質予測を行うため, まず簡易推定式を用いて年蒸発散量を算出し, 年流 出量 $(\mathrm{mm})$ の広域推定を行った. そして, 年流出 量と流出窒素ポテンシャルの広域推定の結果を重ね 合わせることにより, 渓流水中の硝酸態窒素濃度ポ テンシャル $\left(\mathrm{mg} \mathrm{N}^{-1} \mathrm{~L}^{-1}\right)$ を広域的に推定した。それ らの結果を既往の実測值と比較し, 手法の妥当性を 検証した。

\section{II. 方法}

\section{1. 対象地域の概要}

矢作川は長野県の大川入山（標高 $1,908 \mathrm{~m} ）$ に源 を発し, 長野・岐阜・愛知の三県を流れ, 三河湾に 注ぐ西三河を代表する河川である（図一1）。幹線流

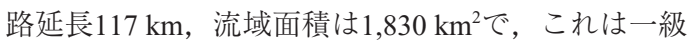
河川の平均的な值となっている（国土交通省河川局, 2006）。矢作川流域を含む東海地方の気候は，夏期の 高温・多雨, 冬期の低温・乾燥に特徵付けられる太 平洋側の気候条件下にある。流域の地形は, 源流部 から豊田市付近までの山地・丘陵地と, 豊田市付近 以南の平野部に大別される（豊田市矢作川研究所, 2006). 森林は主に山地・丘陵地に分布し, 流域の74 \%を占める (1,354 km², Ito et al., 2007). 流域内には約 1,900 mの標高差があり, 気温および降水量は上流 から下流にかけて変化する。このような気候の変化 に対応して, 流域内には様々な植生が存在する (Ito et al., 2007). 最上流部には冷温帯性の天然落葉広 葉樹林 (森林面積全体の 7 \% , 優占樹種はブナ (Fagus crenata), ミズナラ (Quercus crispula), 以 下同様) が分布し, 上～中流部には人工林 (51\%, ス ギ ( Cryptomeria japonica) , ヒノキ ( Chamaecyparis obtusa), 上流部にカラマツ (Larix kaempferi), 主に中 流部にアカマツ(Pinus densiflora)) が植栽されている. 中〜下流部には林齢がおおよそ40年以下の温帯性落 葉広葉樹二次林 (15\%, コナラ (Quercus serrata), クリ (Castanea crenata) ) が分布する (只木ら，2000).下 流部には砂防用に植栽された林分を含むマツ林 $(26$

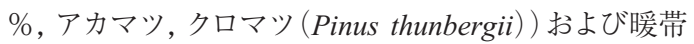
性の常緑広葉樹林 (1 \%, アラカシ (Quercus glauca) 等）が分布する。一方, 土壇も上流部と下流部で異

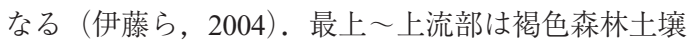
（国土数值情報における土壤統計群の名称，林野土壤 分類（土じょう部, 1976）における土壤型 $\mathrm{B}_{\mathrm{D}}$ および $\mathrm{B}_{\mathrm{D}}$ (d) に該当，以下同様）(全森林面積の $26 \%$ ) が卓越し, 乾性褐色森林土壤 $\left(\mathrm{B}_{\mathrm{A}}, \mathrm{B}_{\mathrm{B}}\right)$ も点在す

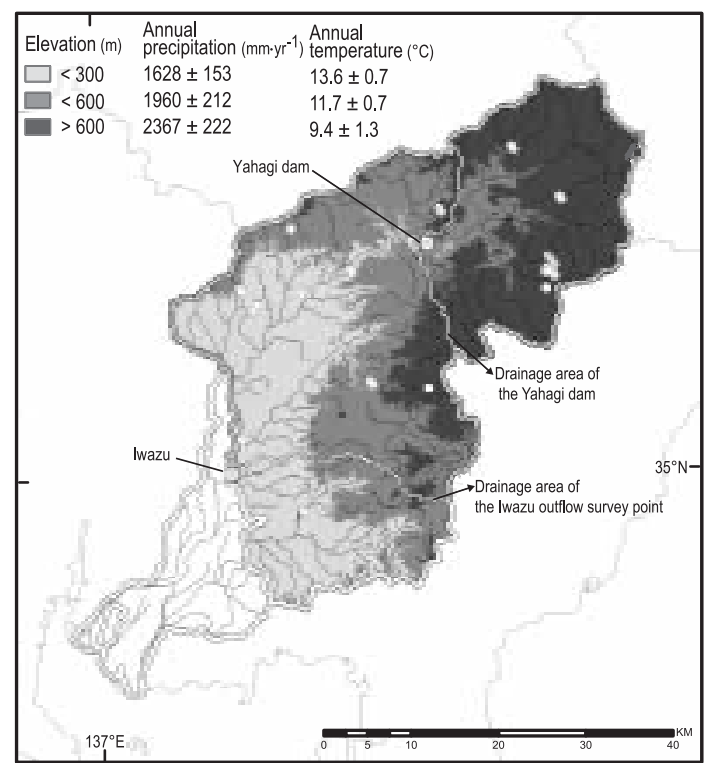

白太線は矢作川流域を, 実線は矢作川流路を示す。 $\bigcirc$ : 表層鉱質 土塞試料採取位置, $\otimes:$ : 流量測定点. 各測定点を通過する白線は 各測定点に対する集水域を示す。

Broad double white lines and black lines indicate the Yahagi watershed and streams of the Yahagi River, respectively. White circles and squears with $\mathrm{X}$ indicate locations of soil sampling points and outflow survey points, respectively. Narrow double white lines are borders of drainage areas of the two outflow survey points.

図-1 矢作川流域標高分布図

Fig.1 Study sites; the Yahagi River watershed and digital elevation model. 
る。中流部には乾性褐色森林土壤 $\left(\mathrm{B}_{\mathrm{A}}, \mathrm{B}_{\mathrm{B}}\right)$ が卓越 する。乾性褐色森林土壤 $\left(\mathrm{B}_{\mathrm{A}}, \mathrm{B}_{\mathrm{B}}\right)$ は全体で全森林 面積の $35 \%$ に達する。下流部には乾性褐色森林土 壤 (黄褐系) $\left(y \mathrm{~B}_{\mathrm{A}}, y \mathrm{~B}_{\mathrm{B}}\right)$ (全森林面積の $\left.20 \%\right)$ や乾 性褐色森林土壤（赤褐系） $\left(r \mathrm{~B}_{\mathrm{A}}, r \mathrm{~B}_{\mathrm{B}}\right.$ ) (全森林面積 の6％）などが多い。また，森林域の大半の地質は 領家帯に属し, 主に花崗岩類より構成される.

矢作川流域では1879年の明治用水を諸端として 種々の水資源開発が行われており, 河川利用率は平 均 $40.8 \%(1977-1995)$ と全国有数の值となってい る (豊田市矢作川研究所, 2006)。さらに, 矢作川 は 140 万人に飲料水を供給していること, 流出先の 三河湾が富栄養化による問題が生じやすい閉鎖湾で あることなどから，各般の水質保全対策が講じられ ている (高橋ら，2000）。このように矢作川流域の 森林が有する水源かん養機能に対する社会的な期待 は極めて大きいと考えられる。

\section{GISデータ}

国土数值情報（国土地理院，1998年発行; 国土 地理院, 1998), 数值地図 $50 \mathrm{~m}$ メッシュ（標高）(国 土地理院，1997年7月1日発行), 環境省自然環境保全 基礎調査第5回基礎調查（1992-1996）(環境省, 2001), メッシュ気候值2000 (気象庁, 2000年6月発行, 19712000年の平年值統計) をもとに, 優占樹種, 表層地 質, 土壤型, 標高, 微地形, 斜面方位, 気温, 降水 量, 全天日射量を50 mメッシュのラスタGISデータ に変換してデータセットとして整備した（表一1）. 優占樹種, 表層地質, 土壤型データの各個別值は元 データを再分類して作成した。微地形は標高データ を用いた地形解析 (斜面傾斜角度・水系網解析によ る累積流入メッシュ数の算出）により，田村（1996） の微地形単位を参考に行った。矢作川下流に位置す

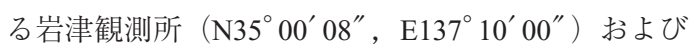
中流に位置する矢作ダム $\left(\mathrm{N} 35^{\circ} 14^{\prime} 07^{\prime \prime}, \mathrm{E} 137^{\circ} 24^{\prime}\right.$ $\left.57^{\prime \prime}\right)$ の集水域を水系網解析によって求め（図一1), 集水域内の土地利用率を計算した. GIS解析に米ESRI 社製ArcView9.1を使用した。

\section{3. 流出窒素ポテンシャルの広域推定}

矢作川流域に存在する森林タイプを網羅すること を主眼に表層土壤採取地点を決定し, 表層鉱質土壤 試料 $(0-5 \mathrm{~cm})$ を矢作川流域から 50 点, 隣接流域か ら6点採取した（図ー1）。採取した土壤はIto et al. (2007) と同様に $30{ }^{\circ} \mathrm{C} \cdot$ 最大容水量の $60 \%$ の土壤含
水率の条件下で28日間室内培養し, 窒素無機化能 · 硝化能の測定を行った (土壤環境分析法編集委員会 編, 1996; 森林立地調査法編集委員会編, 1999). 培 養期間中に生成した硝酸態窒素の量 $\left(\mathrm{Mg} \mathrm{N} \cdot \mathrm{kg} \mathrm{soil}^{-1}\right)$ を算出し，それに細土容積重 $\left(\mathrm{Mg}\right.$ soil $\left.\cdot \mathrm{m}^{-3}\right)$ と深さ $(5 \mathrm{~cm})$ を乗じて, 鉱質土壤表層 $0-5 \mathrm{~cm}$ における硝 酸態窒素生成量を面積あたりに換算した値を流出窒 素ポテンシャル $\left(\mathrm{Mg} \mathrm{N} \cdot \mathrm{km}^{-2}\right)$ と定義した.

土壤試料採取地点の立地環境特性を説明変数とし て, 流出窒素ポテンシャルを予測する一般線形モデ ル（GLM）を作成した。モデルに使用する説明変 数として, 標高. 斜面傾斜角 - 斜面方位 - 亜小地形 単位・母材·土壤型・優占樹種の 7 種類を候補に選 んだ. 各説明要因内の水準は, 広域評価を前提に再 検討を行い, 広域評価モデルの入力に用いる GIS データセットに準じて決定した（表一1）。すべての 説明変数の組合せを試行し, 自由度調整済み $\mathrm{R}^{2}$ 值が 最も高くなる組合せを最適モデルとして選択した。 作成したモデルにII. 2で整備したGISデータセット を入力し, 流出窒素ポテンシャルを $50 \mathrm{~m}$ メシュで 推定した.

\section{4. 年流出量の広域推定}

矢作川流域に扮ける流出量（面積あたりの流出 量, 比流量, $\mathrm{mm}$ ) の広域分布を推定するため, ま ず森林流域からの蒸発散量を50 mメッシュごとに月 単位で計算した。蒸散量と遮断量を基礎式として組 み合わせた下記のような簡便な蒸発散量推定式を用 いた（小松ら，2005）.

$$
E=\alpha\{\Delta /(\Delta+\gamma)\}(R n-G) / \lambda+\beta P
$$

ここで, $\mathrm{E}$ : 蒸発散量 $\left(\mathrm{mm} \cdot \mathrm{d}^{-1}\right), \mathrm{Rn}$ : 純放射量 $\left(\mathrm{MJ} \cdot \mathrm{m}^{-2}\right)$, $\mathrm{G}$ : 地中熱流量 $\left(\mathrm{MJ} \cdot \mathrm{m}^{-2}\right), \mathrm{P}$ : 降水量 $\left(\mathrm{mm} \cdot \mathrm{mo}^{-1}\right), \lambda$ : 水の蒸発潜熱 $\left(2.545 \mathrm{MJ} \cdot \mathrm{kg}^{-1}\right), \alpha$ : Priestley-Taylor係 数, $\rho$ : 遮断率, $\Delta$ : 飽和水蒸気圧曲線の勾配, $\gamma$ : 乾 湿計定数 $\left(\mathrm{hPa} \cdot \mathrm{K}^{-1}\right)$ とする. また, 式1の右辺第一項は 樹冠が乾いているときの蒸発散量（以下，蒸散量） を表し, Priestley-Taylor係数 $a$ に平衡蒸発量を乗じて 推定している。 $a$ は蒸散量が平衡蒸発量に対してど のくらいの割合を占めているかを意味し, 植生の影 響を評価したパラメータとされる(小松ら, 2005). 右辺第二項は樹冠が濡れているときの蒸発散量（以 下, 遮断蒸発量) を表し, 降水量Pに遮断蒸発の効率 (遮断率) を表現するパラメータ $/$ を乗じて推定して いる. のは数ケ月以上など比較的長期の時間スケー 
表－1 GISデータセットおよび整備作業の一覧.（a）名義変数データ，（b）連続変数データ.

Table 1 GIS Datasets and preparation processes: (a) categorical data; (b) continuous data.

(a) 名義変数データ (categorical data)

\begin{tabular}{|c|c|c|c|c|}
\hline \multirow{2}{*}{ 項目 (variable) } & \multicolumn{2}{|c|}{$\begin{array}{c}\text { 元データの諸元 } \\
\text { (original data properties) }\end{array}$} & \multirow{2}{*}{$\begin{array}{c}\text { 変換作業 } \\
\text { (preparation) }\end{array}$} & \multirow{2}{*}{$\begin{array}{c}\text { 再分類後の個別值 } \\
\text { (reclassified item) }\end{array}$} \\
\hline & $\begin{array}{l}\text { デー夕名, 入手元 } \\
\text { (data name, source) }\end{array}$ & $\begin{array}{c}\text { 解像度 } \\
\text { (resolution) }\end{array}$ & & \\
\hline $\begin{array}{l}\text { 優占樹種 } \\
\text { (dominant tree species) }\end{array}$ & $\begin{array}{c}\text { 第5回自然環境保全 } \\
\text { 基礎調査, } \\
\text { 環境省 }\end{array}$ & - & $\begin{array}{c}\text { ポリゴンからラスタ化 } \\
\text { (rasterization of } \\
\text { polygon data) }\end{array}$ & $\begin{array}{l}\text { マツ,シイ・カシ,カラマツ,コナラ, } \\
\text { スギ・ヒノキ,ブナ,ミズナラ }\end{array}$ \\
\hline $\begin{array}{l}\text { 土潩型 } \\
\text { (soil type) } \\
\text { 母材 } \\
\text { (parent material) }\end{array}$ & $\begin{array}{l}\text { 国土数值情報, } \\
\text { 国土地理院 }\end{array}$ & $\begin{array}{l}\text { 3次メッシュ } \\
\text { (third mesh) }\end{array}$ & $\begin{array}{l}\text { メッシュ分割 } \\
\text { (mesh division) }\end{array}$ & $\begin{array}{l}\text { 褐色森林土, } \\
\text { 乾性黄色系褐色森林土, } \\
\text { 乾性赤色系褐色森林土, その他 } \\
\text { 花崗岩, 堆積岩, 変成岩 }\end{array}$ \\
\hline $\begin{array}{l}\text { 亜小地形単位 } \\
\text { (geomorphic unit) } \\
\text { 斜面方位 } \\
\text { (slope orientation) }\end{array}$ & $\begin{array}{c}\text { 数値地図 } 50 \mathrm{~m} \\
\text { メッシュ(標高), } \\
\text { 国土地理院 }\end{array}$ & $50 \mathrm{~m}$ & $\begin{array}{c}\text { 地形解析 } \\
\text { (terrain analysis) }\end{array}$ & $\begin{array}{l}\text { 頂部平坦面, 頂部斜面, } \\
\text { 上部谷壁斜面, 下部谷壁斜面, } \\
\text { 谷頭凹地, 谷底面·麓部斜面 } \\
\text { N, NE, E, SE, S, SW, W, NW }\end{array}$ \\
\hline
\end{tabular}

(b) 連続変数データ (continuous data)

\begin{tabular}{|c|c|c|c|c|}
\hline \multirow{2}{*}{ 項目 (variable) } & \multicolumn{3}{|c|}{$\begin{array}{c}\text { 元データの諸元 } \\
\text { (original data properties) }\end{array}$} & \multirow{2}{*}{$\begin{array}{c}\text { 変換作業 } \\
\text { (preparation) }\end{array}$} \\
\hline & $\begin{array}{l}\text { デー夕名, 入手元 } \\
\text { (data name, source) }\end{array}$ & $\begin{array}{c}\text { 解像度 } \\
\text { (resolution) }\end{array}$ & $\begin{array}{l}\text { 単位, 有効桁 } \\
\text { (unit, digit) }\end{array}$ & \\
\hline $\begin{array}{l}\text { 標高 } \\
\text { (elevation) }\end{array}$ & $\begin{array}{c}\text { 数値地図 } 50 \mathrm{~m} \\
\text { メッシュ(標高), } \\
\text { 国土地理院 }\end{array}$ & $50 \mathrm{~m}$ & $\begin{array}{c}\mathrm{m}, \\
\text { 整数部 }\end{array}$ & $\begin{array}{l}\text { なし } \\
\text { (none) }\end{array}$ \\
\hline $\begin{array}{l}\text { 月平均気温 } \\
\text { (monthly air temperature) } \\
\text { 月平均降水量 } \\
\text { (monthly precipitation) } \\
\text { 月間積算全天日射量 } \\
\text { (monthly radiation) }\end{array}$ & $\begin{array}{c}\text { メッシュ気候值 } 2000, \\
\text { 気象庁 }\end{array}$ & $\begin{array}{l}\text { 3次メッシュ } \\
\text { (third mesh) }\end{array}$ & $\begin{array}{c}{ }^{\circ} \mathrm{C}, \\
\text { 小数第一位 } \\
\mathrm{mm} \cdot \mathrm{mo}^{-1}, \\
\text { 小数第一位 } \\
\mathrm{MJ} \cdot \mathrm{m}^{-2} \cdot \mathrm{mo}^{-1}, \\
\text { 小数第二位 }\end{array}$ & $\begin{array}{l}\text { メッシュ分割 } \\
\text { (mesh division) } \\
\text { メッシュ分割 } \\
\text { (mesh division) } \\
\text { 日積算量の月間平均值を } \\
\text { 変換した後にメッシュ分割 } \\
\text { (calculation from daily radiation, } \\
\text { and mesh division) }\end{array}$ \\
\hline
\end{tabular}

ルにおいて一定の值に収束し, 遮断蒸発に対するサ イトの特性を表現したパラメータであるとされる (小松ら, 2005).

さらに式1における純放射量Rnは以下の推定式に よって求めた。

$$
R n=R_{\text {shading }} \cdot\left[R n^{*} / S \downarrow\right]
$$

ここで, $\mathrm{R}_{\text {shading }}$ : メッシュ気候值の地形遮断が有る ときの全天日射量 $\left(\mathrm{MJ} \cdot \mathrm{m}^{-2}\right)$ (ここでは下向き短波 放射量 $\mathrm{S} \downarrow$ にほぼ等しいとみなす)， $\mathrm{Rn} * \mathrm{~S} \downarrow ： 日$ 中・正のみの純放射量Rn*を下向き短波放射量 $\mathrm{S} \downarrow$ で
除した值 (小松ら，2005)。式1，2に代入したパラ メー夕は表一2に示す。式1，2は本来日単位で計算す るものであるが, 本稿では簡便化のため月単位で計 算しており, 代入したパラメータも月単位ないしは 通年值となっている。これらの仮定の妥当性は考察 で検討する。

各メッシュの月蒸発散量を合計して年蒸発散量を求 め, メッシュ気候值2000の3次メッシュ年降水量デー 夕を50 mメッシュに分割して算出した各メッシュの 年降水量 $\left(\mathrm{mm} \cdot \mathrm{yr}^{-1}\right)$ から差し引いて年流出量 $\left(\mathrm{mm} \cdot \mathrm{yr}^{-1}\right)$ を推定した。岩津観測所における流量お 


$$
\text { 表一2 流出量推定モデルパラメータ }
$$

Table 2 Parameters of the outflow prediction model.

\begin{tabular}{|c|c|c|c|c|}
\hline & パラメー夕(式1) & 優占樹種 (月) & 值 / 近似式 & 出 \\
\hline$\alpha$ & $\begin{array}{l}\text { Priestley-Taylor 係数 } \\
\text { (dimensionless) }\end{array}$ & $\begin{array}{l}\text { カラマツ/スギ・ヒノキ/マツ (通年) } \\
\text { ブナミズナラ/コナラ/シイ・カシ (通年) }\end{array}$ & $\begin{array}{l}0.60 \\
0.82\end{array}$ & $\begin{array}{l}\text { 小松ら, } 2005^{1)} \\
\text { 小松ら, } 2005^{2)}\end{array}$ \\
\hline$\Delta /(\Delta+\gamma)$ & $\begin{array}{l}\Delta: \text { 飽和水蒸気圧曲線の勾配, } \\
\gamma: \text { 乾湿計定数 }\left(\mathrm{hPa} \cdot \mathrm{K}^{-1}\right)\end{array}$ & & $0.0128^{*} \mathrm{~T}+0.418^{3)}$ & \\
\hline $\mathrm{Rn}$ & 純放射量 $\left(\mathrm{MJ} \cdot \mathrm{m}^{-2}\right)^{4)}$ & & $\begin{array}{c}\left(\mathrm{R}_{\text {shading }}\right) \\
*(\mathrm{Rn} * \mathrm{~S} \downarrow)\end{array}$ & 小松ら, 2005 \\
\hline G & 地中熱流量 $\left(\mathrm{MJ} \cdot \mathrm{m}^{-2}\right)$ & & $\mathrm{Rn}$ の5\% & $\begin{array}{l}\text { 近藤ら, } 1992 ; \\
\text { 清水ら, 1994; } \\
\text { 神田ら，1997 5) }\end{array}$ \\
\hline Z & 水の蒸発の潜熱 $\left(\mathrm{MJ} \cdot \mathrm{kg}^{-1}\right)$ & & 2.45 & \\
\hline$\beta$ & 遮断率 & $\begin{array}{l}\text { カラマツ }(4-10) \\
\text { カラマツ }(11-3) \\
\text { スギ・ヒノキ (通年) } \\
\text { マツ(通年) } \\
\text { ブナミズナラ (5-10) } \\
\text { ブナミズナラ (11-4) } \\
\text { コナラ (4-10) } \\
\text { コナラ (11-3) } \\
\text { シイ・カシ (通年) }\end{array}$ & $\begin{array}{l}0.23 \\
0.11 \\
0.20 \\
0.21 \\
0.18 \\
0.09 \\
0.20 \\
0.15 \\
0.20 \\
\end{array}$ & $\begin{array}{l}\text { 服部, } 1985^{6)} \\
\text { 服部, } 1985^{7)} \\
\text { 服部, } 1985^{8)} \\
\text { 服部, } 1985^{9)} \\
\text { 服部, } 1985^{10)} \\
\text { 服部, } 1985^{7)} \\
\text { 服部, } 1985^{11)} \\
\text { 服部, } 1985^{12)} \\
\text { 服部, } 1985^{11)} \\
\end{array}$ \\
\hline $\mathrm{P}$ & 月平均降水量 $\left(\mathrm{mm} \cdot \mathrm{mo}^{-1}\right)$ & & & メッシュ気候值2000 \\
\hline $\mathrm{R}_{\text {shading }}$ & $\begin{array}{l}\text { 地形遮断が有るときの全天日射量 } \\
\left(\mathrm{MJ} \cdot \mathrm{m}^{-2} \cdot \mathrm{mo}^{-1}\right)\end{array}$ & & & メッシュ気候値2000 \\
\hline
\end{tabular}

1) 論文中で樹高 10-20 m の針葉樹林の暖候期の值として記載;

2) 論文中で温帯広葉樹林の暖候期の值として記載;

3） $\mathrm{T}=$ 月平均気温 $\left({ }^{\circ} \mathrm{C}\right)$,使用デー夕は表 1 参照;

4) パラメー夕(式2)参照;

5）各出典中のRnに対するG の值は, 4 \%程度 (近藤ら,1992),8 月で約5\%(神田ら,1997 より判読),4 月で約6\%(清水ら,1994より判読)であった;

6) 出典中に引用されたカラマツ林 (北海道·岩手)の值の平均值;

7) 着葉期の值の 50 \%と仮定した;

8) 出典中に引用されたスギ・ヒノキ林(群馬),ヒノキ林(茨城),アカマツ・ヒノキ林(滋賀),ヒノキ林 (京都)の值の平均值;

9）出典中に引用されたアカマツ林 (岩手),アカマツ・ヒノキ林(滋賀)の值の平均値；

10) 出典中に引用された5-11 月のブナ林 (栃木)の值;

11) 出典中に引用された広葉樹 (京都)の值, 測定林分は常緑のソヨゴが8 割をしめる;

12) 林相は常落5 割ずつと仮定し,着葉期の值の $75 \%$ \%をえた.

\begin{tabular}{|c|c|c|c|c|c|}
\hline & \multirow{2}{*}{ パラメータ(式2) } & \multirow{2}{*}{ 月 } & \multicolumn{3}{|c|}{ 優占樹種 (月) } \\
\hline & & & カラマツハブナミズナラ11) & マツ/スギ・ヒノキ12) & コナラハイ・カシ13) \\
\hline \multirow{12}{*}{$\mathrm{Rn} * / \mathrm{S} \downarrow 10)$} & \multirow{12}{*}{$\begin{array}{c}\mathrm{Rn} * \text { : 日中·正のみの純放射量, } \\
\mathrm{S} \downarrow \text { : 下向き短波放射量 } \\
\text { (dimensionless) }\end{array}$} & 1 & 0.58 & 0.73 & 0.63 \\
\hline & & 2 & 0.64 & 0.76 & 0.67 \\
\hline & & 3 & 0.68 & 0.78 & 0.72 \\
\hline & & 4 & 0.68 & 0.81 & 0.71 \\
\hline & & 5 & 0.71 & 0.79 & 0.73 \\
\hline & & 6 & 0.74 & 0.82 & 0.77 \\
\hline & & 7 & 0.80 & 0.84 & 0.89 \\
\hline & & 8 & 0.80 & 0.84 & 0.85 \\
\hline & & 9 & 0.75 & 0.82 & 0.81 \\
\hline & & 10 & 0.66 & 0.79 & 0.72 \\
\hline & & 11 & 0.62 & 0.75 & 0.68 \\
\hline & & 12 & 0.58 & 0.73 & 0.65 \\
\hline
\end{tabular}

10) 小松ら (2005)において, $\approx$ (Priestley-Taylor係数)が日中 (入力放射量がプラスである時間帯)に対して定義されているため,ここでもRn*を使う. なお,小松ら (2005) は年間を通じて Rn*/S $\downarrow=0.8 を$ 仮定してよいとしているが,本稿では月別の値を用いた;

11) 広葉樹林 (常緑 $60 \%$, 落葉 $40 \%$ ) (愛知)の值.カラマッハブナミズナラの三樹種には落葉期と着葉期の違いが最も著しいデータセットを適用した;

12) スギ林 (熊本)とヒノキ林(茨城)の平均值；13）広葉樹林 (常緑 $30 \%$, 落葉70\%)（愛知) と広葉樹林 (常緑60\%, 落葉40\%)(愛知)の平均値. 
よび矢作ダムへの流入量を, II. 2で求めた各地点の 集水域に含まれるメッシュの総和として計算し, 岩 津観測所と矢作ダムにおける実測值と比較した。

\section{5. 渓流水窒素濃度ポテンシャルの広域推定}

各メッシュに扔ける流出窒素ポテンシャルを年流 出量で除した值を，渓流水窒素濃度ポテンシャルと 定義した。溪流水窒素濃度ポテンシャルの広域分布 傾向を既往の渓流水硝酸態窒素濃度の実測值と比較 した。なお，渓流水窒素濃度ポテンシャルは実際の 窒素循環系で卓越する生物による吸収や脱窒による 消失を含んでいないため，実際の渓流水窒素濃度よ

表－3 流出窒素ポテンシャル予測モデルにおける各説 明変数の係数

Table 3 Multiple regression models with nitrogen loss potentials as the dependent variable, and explanatory variables describing geographical factors of individual sample points.

\begin{tabular}{|c|c|}
\hline 項 目 (variable) & Coefficient \\
\hline 切片 & $1.57 * * * *$ \\
\hline 標高 & $0.71 \times 10^{-3}$ n.s. \\
\hline 斜面方位 & $* *$ \\
\hline $\mathrm{W}$ & 0.95 \\
\hline NW & 0.93 \\
\hline SW & 0.25 \\
\hline $\mathrm{N}$ & -0.15 \\
\hline $\mathrm{NE}$ & -0.21 \\
\hline S & -0.44 \\
\hline SE & -0.64 \\
\hline $\mathrm{E}$ & -0.69 \\
\hline 亜小地形単位 & $* *$ \\
\hline 上部谷壁 & 0.60 \\
\hline 谷底 & 0.48 \\
\hline 谷頭 & 0.04 \\
\hline 下部谷壁 & -0.49 \\
\hline 頂稜 & -0.64 \\
\hline 母材 & n.s. \\
\hline 変成岩 & 0.56 \\
\hline 花崗岩 & -0.11 \\
\hline 堆積岩 & -0.45 \\
\hline 優占樹種 & $* *$ \\
\hline ブナ & 1.94 \\
\hline カラマツ & 0.02 \\
\hline スギ・ヒノキ & -0.08 \\
\hline ミズナラ & -0.29 \\
\hline コナラ & -0.37 \\
\hline シイ・カシ & -0.56 \\
\hline アカマツ & -0.66 \\
\hline
\end{tabular}

り恒常的に高く，平水時における渓流水窒素濃度の 最大值の目安と考えられる。

\section{III. 結果}

\section{1. 流出窒素ポテンシャル}

流出窒素ポテンシャルの変動を説明する説明変数 として標高 - 斜面方位 - 覀小地形単位 - 母材 - 優占 樹種が選択された（表一 3 , 自由度調整済み $R^{2}=0.66$, $p<0.0001)$. 選択された説明変数を用いた一般線形 モデルで流出窒素ポテンシャルの広域分布パターン を予測したところ，流出窒素ポテンシャルは広域的 には上流で大きく下流で小さい傾向が認められた (図一2)。この傾向は優占樹種の広域的分布傾向に 依拠しており, 硝酸態窒素生成量が大きいブナ林や 人工林が上流部に分布し, 小さいコナラ林やマツ林 が下流部に分布するという流域内の分布特性を反映 していた。一方，流出窒素ポテンシャルの局所的な 変動には斜面方位と亜小地形単位が影響していた。 斜面方位における傾向は明瞭で, 西向き斜面が正の， 東向き斜面が負の影響を示した（表一-3）。

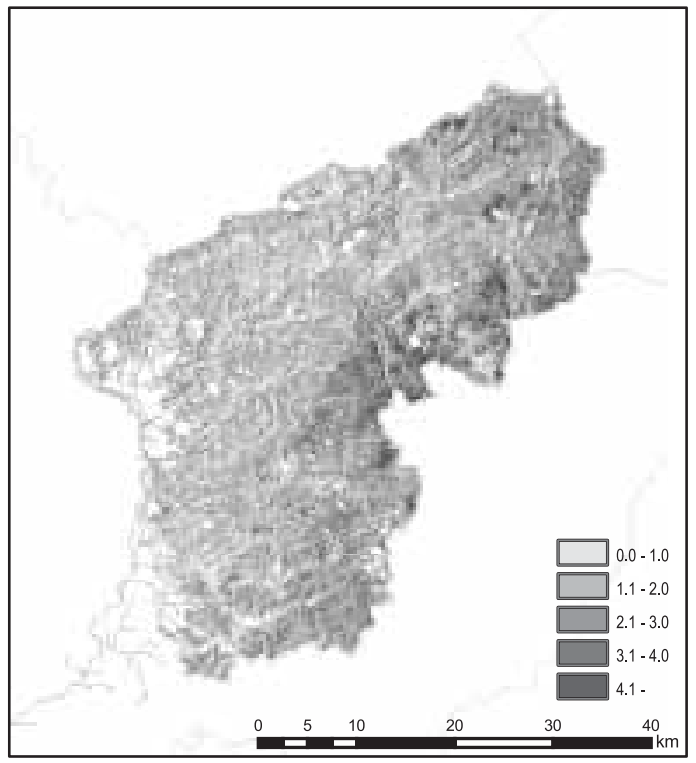

図 - 2 流出窒素ポテンシャル広域分布図 (単位: $\mathrm{Mg} \mathrm{N} \cdot \mathrm{km}^{-2}$ ) Fig.2 Regional distribution of nitrogen loss potentials in the Yahagi watershed. 


\section{2. 年流出量}

矢作川流域森林域の年降水量は $1,374-2,750 \mathrm{~mm}$ の 範囲にあり，森林域に含まれる50 mメッシュ単位の 年平均降水量（SD）は1,988 $362 \mathrm{~mm} ゙$ あった。年 降水量分布は上流で大きく下流で小さい傾向が顕著 に認められ, 年平均降水量は標高 $600 \mathrm{~m}$ 以上の地域 で2,367士222 mm, 標高300 m以上600 m未満の地域 で1,960土212 mm, 標高300 m未満の地域で1,628土 $153 \mathrm{~mm}$ であった。 また, 年降水量に対する年流出 量の割合も上流で大きく下流で小さい傾向が認めら れた (表一4)。それらの結果として, 年流出量 $\left(\mathrm{mm} \cdot \mathrm{yr}^{-1}\right)$ は上流で大きく下流で小さい傾向が顕著 に認められた（図一3）。また，この傾向は同一樹種 内で比較したときにも認められた（表一4）.

蒸発散量推定式の精度評価のために, 各メッシュ の年流出量推定值と矢作川流域森林域の最下流点に 位置する岩津観測点（図一-1）における実測年流量 を比較した (表一5)。岩津観測点集水域からの年流 出量推定値は1,221 mmだった。この值は気候值とし て1971-2000年の平年值であるメッシュ気候值2000 を利用して推定した。一方，1993年から2002年まで の実測值の平均 $\pm \mathrm{SD}$ は804 $2331 \mathrm{~mm}$ で值域は422-

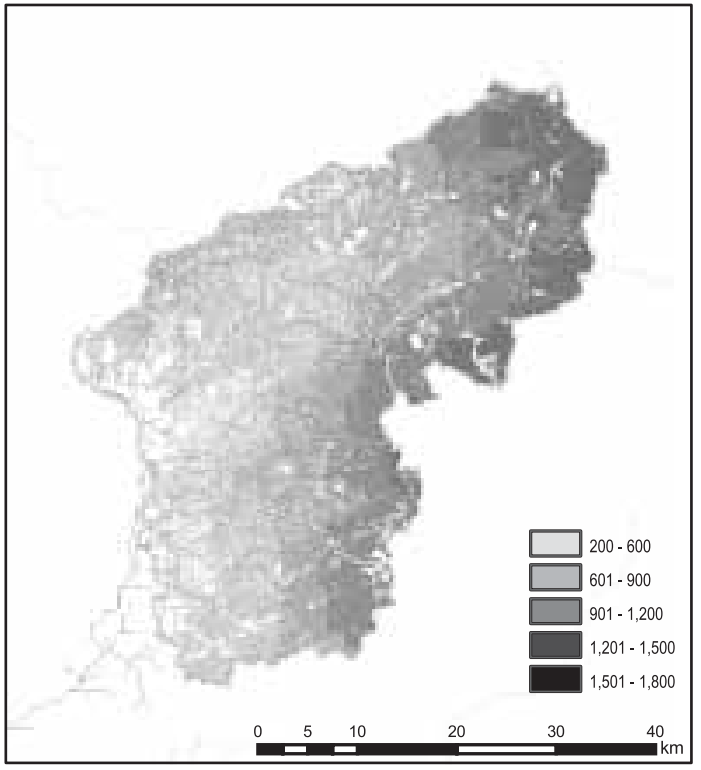

図-3 年間流出量広域分布図 (単位: $\mathrm{mm} \mathrm{yr}^{-1}$ )

Fig.3 Regional distribution of annual outflows in the Yahagi watershed.

1,398 mmだった。このように推定值が実測值より過 大となる傾向が認められた。 なお，降水量は岩津観

表-4 流域内の相対的な位置による推定值（平均 $\pm \mathrm{SD}$ ）の違い

Table 4 Averages and SD of predicted values and precipitation along the elevation gradient.

\begin{tabular}{|c|c|c|c|c|c|c|c|c|c|}
\hline 優占樹種 & 標高 (m) & $\begin{array}{l}\text { 流出窒素 } \\
\text { ポテンシャル } \\
\left(\mathrm{Mg} \mathrm{N} \cdot \mathrm{km}^{-2}\right)\end{array}$ & $\begin{array}{l}\text { 年流出量 } \\
\left(\mathrm{mm} \cdot \mathrm{yr}^{-1}\right)\end{array}$ & $\begin{array}{c}\text { 渓流水窒素 } \\
\text { 濃度ポテンシャル } \\
\left(\mathrm{mg} \mathrm{N} \cdot \mathrm{L}^{-1}\right)\end{array}$ & $\begin{array}{l}\text { 年降水量 } \\
\left(\mathrm{mm} \cdot \mathrm{yr}^{-1}\right)\end{array}$ & $\begin{array}{c}\text { 年蒸発散量 } \\
\left(\mathrm{mm} \cdot \mathrm{yr}^{-1}\right)\end{array}$ & $\begin{array}{l}\text { 年蒸散量 } \\
\left(\mathrm{mm} \cdot \mathrm{yr}^{-1}\right)\end{array}$ & $\begin{array}{l}\text { 年遮断量 } \\
\left(\mathrm{mm} \cdot \mathrm{yr}^{-1}\right)\end{array}$ & $\begin{array}{c}\text { 年降水量に } \\
\text { 対する年流 } \\
\text { 出量の割合 } \\
(\%)\end{array}$ \\
\hline マツ & $\begin{array}{l}<300 \\
300<, \\
<600 \\
<600\end{array}$ & $\begin{array}{l}1.1 \pm 0.9 \\
1.1 \pm 0.9 \\
1.3 \pm 0.9 \\
\end{array}$ & $\begin{array}{c}712 \pm 104 \\
913 \pm 103 \\
1220 \pm 222\end{array}$ & $\begin{array}{l}1.7 \pm 1.3 \\
1.3 \pm 1.0 \\
1.2 \pm 0.8 \\
\end{array}$ & $\begin{array}{l}1613 \pm 127 \\
1847 \pm 126 \\
2204 \pm 267\end{array}$ & $\begin{array}{l}901 \pm 25 \\
935 \pm 25 \\
984 \pm 47 \\
\end{array}$ & $\begin{array}{c}562 \pm 9 \\
547 \pm 9 \\
522 \pm 14 \\
\end{array}$ & $\begin{array}{l}339 \pm 27 \\
388 \pm 27 \\
463 \pm 56\end{array}$ & $\begin{array}{l}44 \pm 3 \\
49 \pm 2 \\
55 \pm 3\end{array}$ \\
\hline コナラ & $\begin{array}{l}<300 \\
300<, \\
<600 \\
<600 \\
\end{array}$ & $\begin{array}{l}1.3 \pm 0.9 \\
1.3 \pm 0.9 \\
1.5 \pm 0.9 \\
\end{array}$ & $\begin{array}{c}561 \pm 111 \\
862 \pm 152 \\
1075 \pm 168\end{array}$ & $\begin{array}{l}2.4 \pm 1.8 \\
1.5 \pm 1.1 \\
1.5 \pm 0.9 \\
\end{array}$ & $\begin{array}{l}1589 \pm 132 \\
1926 \pm 181 \\
2167 \pm 200\end{array}$ & $\begin{array}{l}1028 \pm 24 \\
1064 \pm 31 \\
1092 \pm 34 \\
\end{array}$ & $\begin{array}{l}727 \pm 11 \\
700 \pm 13 \\
682 \pm 13 \\
\end{array}$ & $\begin{array}{l}301 \pm 25 \\
364 \pm 35 \\
410 \pm 38 \\
\end{array}$ & $\begin{array}{l}35 \pm 4 \\
44 \pm 3 \\
49 \pm 3\end{array}$ \\
\hline シイ•ナ & $\begin{array}{l}<300 \\
300< \\
<600 \\
<600\end{array}$ & $\begin{array}{l}1.3 \pm 1.0 \\
1.3 \pm 1.0 \\
2.1 \pm 1.2\end{array}$ & $\begin{array}{c}551 \pm 114 \\
806 \pm 160 \\
1168 \pm 207\end{array}$ & $\begin{array}{l}1.8 \pm 1.6 \\
1.3 \pm 1.1 \\
1.7 \pm 0.9\end{array}$ & $\begin{array}{l}1603 \pm 134 \\
1893 \pm 193 \\
2309 \pm 238\end{array}$ & $\begin{array}{l}1052 \pm 24 \\
1087 \pm 36 \\
1140 \pm 34\end{array}$ & $\begin{array}{l}731 \pm 13 \\
708 \pm 14 \\
679 \pm 20\end{array}$ & $\begin{array}{l}321 \pm 27 \\
379 \pm 39 \\
462 \pm 48\end{array}$ & $\begin{array}{l}34 \pm 4 \\
42 \pm 4 \\
50 \pm 4\end{array}$ \\
\hline こノキ & $\begin{array}{l}<300 \\
300< \\
<600 \\
<600\end{array}$ & $\begin{array}{l}1.7 \pm 1.0 \\
1.7 \pm 1.0 \\
2.0 \pm 1.0\end{array}$ & $\begin{array}{c}842 \pm 169 \\
1073 \pm 182 \\
1361 \pm 174\end{array}$ & $\begin{array}{l}2.1 \pm 1.3 \\
1.6 \pm 1.0 \\
1.5 \pm 0.8\end{array}$ & $\begin{array}{l}1747 \pm 207 \\
2014 \pm 225 \\
2351 \pm 211\end{array}$ & $\begin{array}{l}905 \pm 40 \\
940 \pm 44 \\
990 \pm 38\end{array}$ & $\begin{array}{l}556 \pm 10 \\
538 \pm 10 \\
520 \pm 11\end{array}$ & $\begin{array}{l}349 \pm 41 \\
403 \pm 45 \\
470 \pm 42\end{array}$ & $\begin{array}{l}48 \pm 4 \\
53 \pm 3 \\
58 \pm 2\end{array}$ \\
\hline ミズナラ & $<600$ & $1.9 \pm 1.0$ & $1547 \pm 76$ & $1.3 \pm 0.7$ & $2551 \pm 83$ & $1004 \pm 15$ & $617 \pm 12$ & $387 \pm 12$ & $61 \pm 1$ \\
\hline カラマツ & $<600$ & $2.3 \pm 0.9$ & $1616 \pm 63$ & $1.5 \pm 0.6$ & $2560 \pm 79$ & $944 \pm 21$ & $445 \pm 11$ & $498 \pm 15$ & $63 \pm 1$ \\
\hline ブナ & $<600$ & $4.0 \pm 1.1$ & $1423 \pm 125$ & $3.0 \pm 0.9$ & $2418 \pm 143$ & $995 \pm 20$ & $627 \pm 10$ & $368 \pm 22$ & $59 \pm 2$ \\
\hline
\end{tabular}


表 -5 年流出量に関するモデル推定值と実測值の比較

Table 5 Measurements and estimates of annual emission components for two drainage areas including the Yahagi River watershed.

\begin{tabular}{|c|c|c|c|c|c|}
\hline & \multicolumn{2}{|c|}{ 岩津観測所 } & \multicolumn{2}{|c|}{ 矢作ダム } \\
\hline & & 平均 $\pm \mathrm{SD}\left(\mathrm{mm} \cdot \mathrm{yr}^{-1}\right)$ & 值域 $\left(\mathrm{mm} \cdot \mathrm{yr}^{-1}\right)$ & 平均 $\pm \mathrm{SD}\left(\mathrm{mm} \cdot \mathrm{yr}^{-1}\right)$ & 值域 $\left(\mathrm{mm} \cdot \mathrm{yr}^{-1}\right)$ \\
\hline 実測値 & $\begin{array}{l}\text { 年流出量 1) } \\
\text { 地点降水量 2) }\end{array}$ & $\begin{array}{l}804 \pm 331 \\
1042\end{array}$ & $422-1398$ & $\begin{array}{l}1584 \pm 396 \\
1216\end{array}$ & $948-2224$ \\
\hline 推定値 & $\begin{array}{l}\text { 集水域年流出量 }{ }^{3)} \\
\text { 集水域降水量 }{ }^{4)} \\
\text { 地点降水量 }{ }^{5)} \\
\text { 集水域蒸発散量 6) } \\
\text { 集水域遮断蒸発量 }{ }^{6)} \\
\text { 集水域蒸散量 6) }\end{array}$ & $\begin{array}{l}1221 \\
2028 \pm 362 \\
1579 \\
972 \pm 64 \\
403 \pm 65 \\
569 \pm 70\end{array}$ & $\begin{array}{c}1374-2750 \\
829-1193 \\
217-566 \\
421-746\end{array}$ & $\begin{array}{l}1444 \\
2350 \pm 241 \\
1768 \\
995 \pm 49 \\
445 \pm 56 \\
550 \pm 64\end{array}$ & $\begin{array}{c}1708-2750 \\
871-1186 \\
307-566 \\
421-706 \\
\end{array}$ \\
\hline
\end{tabular}

1) 観測期間:岩津 1993-2002, 矢作夕゙ム1993-2004;

2) 観測期間:岩津 2002 , 矢作ダム $2002 ;$

3）森林以外のセルからは降水がすべて流出するとした值；

4）集水域に含まれるセルの平均値;

5) 観測点を含むセルの值;

6) 森林セルのみを対象とした計算值.

測点の実測值（2002年）が1,042 mm（国土交通省， 2006)，メッシュ気候值2000から算出した岩津観測 点集水域の平均值が2,028 mmだった。また, 蒸散量 の集水域平均（森林セルのみ）は569 mm, 遮断蒸 発量の集水域平均は $403 \mathrm{~mm}$ であり, 蒸発散量に占 める遮断蒸発量の割合は $42 \%$ となった。

同様の比較を，矢作川流域森林域の中間地点に位 置する矢作ダム（図一1）に扔いても行った（表一 5). 年流出量の推定值は $1,444 \mathrm{~mm}$ であり, 1993年 から2004年までの実測值の平均 $\pm \mathrm{SD}$ は $1,584 \pm 396$ $\mathrm{mm}$ で值域は948-2,224 mmだった。平均值の変動の 範囲内ではあるが, 推定值が実測值よりやや過小と なる, 岩津観測点とは逆の傾向が認められた。降水 量は矢作ダムの実測值 (2002年) が1,216 mm (同上), メッシュ気候值2000による矢作ダム集水域の平均值 が2,350 mmだった。蒸散量の集水域平均は550 564 $\mathrm{mm}$, 遮断蒸発量の集水域平均は $445 \pm 56 \mathrm{~mm}$ であっ た。蒸発散量に占める遮断蒸発量の割合は $45 \%$ と なり, 流域全体と比較すると上流域では遮断蒸発量 の割合がより大きくなった。

\section{3. 渓流水窒素濃度ポテンシャル}

流出窒素ポテンシャルを年流出量で除した值で推 定した溪流水窒素濃度ポテンシャルでは, 流出窒素 ポテンシャルと年流出量で共通する広域的傾向が除 算によって打ち消しあった結果, 斜面方位・亜小地 形単位に起因する局所的な違いがより明瞭に認めら れた (図一4). しかしながら同一樹種で溪流水窒素 濃度ポテンシャルを比較すると, 上流域で小さく, 下流域で大きい傾向が認められた（表一4）.

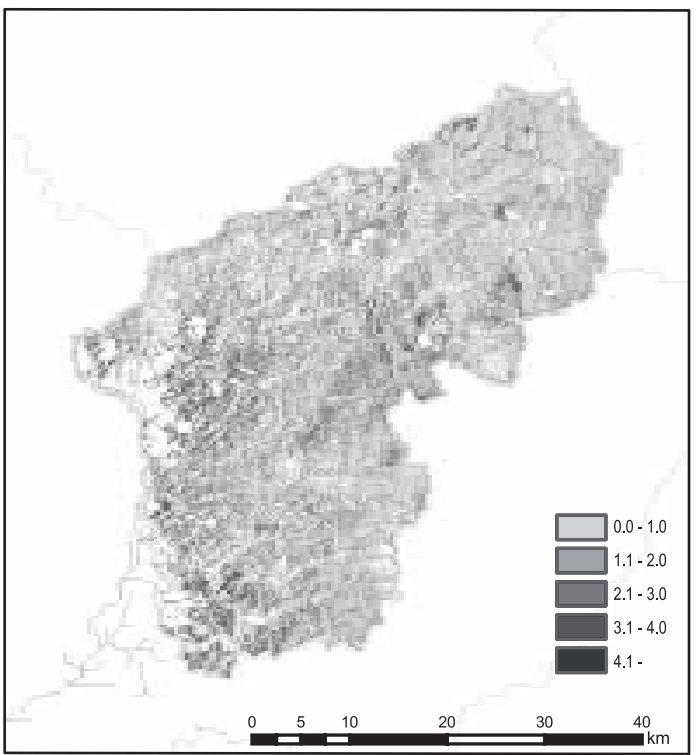

值は図一2に示した流出窒素ポテンシャルを図一3に示した年間 流出量予測值で除したもの.

四-4 渓流水窒素濃度ポテンシャル広域分布図（単位: $\left.\mathrm{mg} \mathrm{N} \cdot \mathrm{L}^{-1}\right)$

Fig.4 Regional distribution of nitrate concentration potentials in the Yahagi watershed.

\section{IV. 考察}

\section{1. 流出窒素ポテンシャル}

ここでは流出窒素ポテンシャル広域推定手法につ いて検討する。流出窒素ポテンシャルの推定精度は それほど高くないが $\left(R^{2}=0.66\right)$ ，これは入力した GISデー夕の精度が主因と考えられる。例えば，今 回用いた環境省植生データではスギとヒノキが一括 して取り扱われていた。そのために，モデルに用い 
た説明要因の水準においてもスギ・ヒノキと一括り にして設定した（表一1，3）。なおスギとヒノキを 別個の水準として入力するとモデルの決定係数は 0.80 まで増加した。 また，林野土壤分類（土じょう 部，1976）による土壤型と土壤中の窒素動態には関 連があるが（吉田ら，1980；沓名ら，1988），土壤 型は説明変数として選択されなかった（表一3）。こ

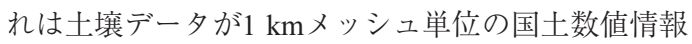
を用いており，この解像度では林野土壤分類を的確 に反映できないためと考えられる。一方で，亜小地 形単位は有力な説明変数 $(p<0.01)$ として選択さ れた (表一3). 亜小地形単位が示す相対的な斜面位 置は土壤型と連関するため, モデルでは亜小地形単 位をもって土壤型の違いをある程度反映したと考え られる。しかしながら, 土畩型の詳細なデータが存 在すればモデルの精度はより向上したと思われる. このように広域評価の精密化のためには, 窒素循環 など各々の目的変数の再現に適した水準分類の変数 をモデルに入力することが必要である。しかしなが ら，森林区分を初めとする既存のGISデー夕は必ず しも個々の目的に対して最適な仕様にはなっていな い. 今後は利用者による変換が容易で，かつデー夕 間の互換性が高いGISデータの整備が求められる.

\section{2. 年流出量}

推定した年流出量の妥当性について，年流出量の 実測值と比較して検討する.

まず，上流部に関して考察する．矢作ダム集水域 に㧍ける年流出量の推定值 $(1,444 \mathrm{~mm})$ は実測值の 変動範囲内 $(1,584 \pm 396 \mathrm{~mm})$ にあり, このことか ら推定值は妥当であるように思われた。しかし，上 流部に㧍ける推定蒸発散量 $(995 \pm 49 \mathrm{~mm}$, 值域871$1,186 \mathrm{~mm}$, 表一5）は気温や降水量が類似の試験地 における既報の実測值と比べると概して過大であっ た。例えば，山形県釜淵森林理水試験地（年平均気 温9.9 ${ }^{\circ} \mathrm{C}$, 年平均降水量 $2,424 \mathrm{~mm}$, 標高 $160-250 \mathrm{~m}$ ) に扔ける年蒸発散量は400-520 mm, 群馬県宝川森 林理水試験地本流流域 (年平均気温 $8.3{ }^{\circ} \mathrm{C}$, 年平均 降水量2,134 mm, 標高805-1,945 m) における年蒸 発散量は590 mm程度と報告されている（服部ら， 2001)。中には, 群馬県宝川森林理水試験地初沢流 域 (年平均気温 $8.3{ }^{\circ} \mathrm{C}$, 年平均降水量 $2,134 \mathrm{~mm}$, 標 高810-1,380 m）に抢ける年蒸発散量值976 mmのよ うに推定蒸発散量の範囲内の值も報告されている
(服部ら，2001).しかし，蒸発散量が1,000 mmを超 える事例は, 温暖多雨地域のスギ林において降水量 が3,000 mmを超えた多雨年に観測されているが (Shimizu et al., 2003), 矢作川上流部と類似の気温や 降水量条件下に限れば，著者らの知りうる範囲では 認められず，本稿での值は過大推定であると思われ る.したがって, 本稿で推定した年流出量はやや過 小推定になっており，推定精度は蒸発散量の推定精 度を上げることで改善されると結論づけられる。な お, 蒸発散量の過大推定をもたらす原因については IV.3で述べる.

次に，下流部について考察する。岩津観測点にお ける年流出量の推定值 $(1,221 \mathrm{~mm})$ は実測值 $(804 \pm$ $331 \mathrm{~mm})$ より過大であった。一方, 下流部での推定 蒸発散量は既往の報告より大きめの值を示した。具 体的には，下流部での推定蒸発散量は860-1,070 mm 程度の值を示したが (表一4), 年平均気温 $15.4{ }^{\circ} \mathrm{C}$ ・ 年平均降水量 $1,632 \mathrm{~mm}$ の東京大学愛知演習林に打け る実測值は650-900 mmとなっており（服部ら， 2001), 今回の推定蒸発散量は実測值の平均かやゃ 大きい值となっている。したがって, 岩津観測点に おける実測值と推定值の誤差は蒸発散量の推定精度 以外の部分に依拠すると推察できる。この䛊差は, ダムに㧍ける湖面蒸発（近藤, 1994）や河道近傍の 蒸発（清水ら，1997）の他に, 農耕地に抢ける水利 用の実態を反映した蒸発散が推定されていないため たと思われる。岩津観測点の集水域内における森林 率は81\%で, 森林以外の土地利用としては農耕地 (10.5\%)，そのうちでも特に水田 $(8.0 \%)$ が卓越 している。本稿では, 森林以外の土地利用がされる セルにおいては, 降水量のすべてが流出すると仮定 したが，湛水期の水田や貯水池などでは森林の75$80 \%$ 程度の蒸発散量が見込まれるため（近藤， 1994），流出量が過大推定になったと考えられる. 同様のことは矢作ダム集水域でも言えるが，矢作ダ 么集水域内の土地利用は森林が圧倒的に卓越し（森 林率91％), 農耕地 $(3.4 \%)$ や水田 $(2.9 \%)$ の割 合も小さいため, 農耕地に扔ける水利用に伴う水消 費の影響は小さかったことが推測される。

\section{3. 年蒸発散量}

年蒸発散量の過大推定をもたらす原因について, 遮断蒸発と蒸散に分けて検討する。

矢作ダム集水域における遮断蒸発量は蒸発散量の 
$45 \%$ を占め，その值は $445 \pm 56 \mathrm{~mm}$ と推定された (表一5).この值は既往の年蒸発散量測定值の75$110 \%$ に達する。遮断蒸発量の過大推定をもたらし た原因としては，次の3つが考えられる。

第一に，遮断率パラメータのが考えられる。日本 の林分に扔いては，気象扔よび林分条件が異なるに も関わらず，遮断率パラメータるが20\%付近に収 束することが認められている（服部，1985; 服部， 1992）。しかしながら，この值をそのまま矢作ダム 集水域に適用した場合, 矢作夕゙ム集水域の年降水量 平均值が2,350 mmであることから，通年 $20 \%$ の遮 断蒸発を仮定すると遮断蒸発量は $470 \mathrm{~mm}$ となり, 遮断蒸発量だけで既往の年蒸発散量測定值に達する 試算となる。本稿では, 落葉による遮断蒸発量の減 少を意図して，カラマツ，ブナ，ミズナラ，コナラ の落葉樹林分においては, 落葉期の $\rho$ を着葉期の

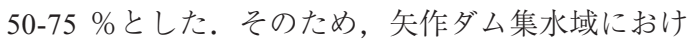

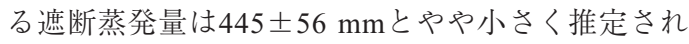
たが，この遮断率パラメータのの与え方には検討の 余地が大きいと思われる。

第二に, 降雨パターンや降雨日数の影響が考えら れる。遮断蒸発には降水量よりも降雨パターンや降 雨日数の方が影響するとされ（近藤，1994）, 遮断 率のはそれらを包含したサイト特性パラメータとし て与える必要がある（小松ら，2005）。しかしなが ら，本稿では優占樹種のみを基準として既往の報告 から遮断率 $\rho$ を決定した。降雨パターンや降雨日数 のような降雨条件や風速・飽差などの気象条件をモ デルに組み込むことで推定が精密化できる可能性は 高い.

第三に，雪の影響が考えられる，矢作ダム集水域 の標高は $881 \pm 258 \mathrm{~m}$ と高く, 冬季には相当量の降雪 が認められる。仮に月平均気温 $0{ }^{\circ} \mathrm{C}$ 以下の月の降雨 量を降雪量と仮定すると，降雪量は $178 \pm 126 \mathrm{~mm}$, 最大で544 mmであり，それらが年降水量に占める 割合は6.8 $4.8 \%$ ．最大で $20 \%$ となる（データ未掲 載)。本稿の試算では降雪の遮断蒸発は降水と区別 していない。しかし, 雪 $\left(0{ }^{\circ} \mathrm{C}\right)$ の昇華に必要な潜 熱は, 同じ温度の水の気化に必要な潜熱の1.13倍と されるなど（山崎，1994）, 降雨と降雪に同じ遮断 率を適用することには疑問が残る。

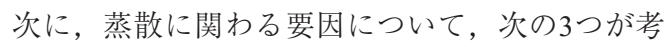
えられる。

第一に, Priestley-Taylor係数 $a$ を優占樹種（針葉 樹・広葉樹）ごとに通年で一定の值を与えた影響が
挙げられる，小松ら（2005）は， $\alpha は$ 季節変化する 值であり, 落葉樹林では落葉期の $\alpha$ は一般的に小さ いことを示唆している。にも関わらず，小松ら （2005）が同論文で示した「暖候期」の $a$ を一定値 として使用したことが，本論での蒸散量の過大推定 をもたらしたと考えられる。その他にも $а$ は植生の 状態 (e.g., LAI, Stannard, 1993 ; Sumner, 1996) や環 境条件 (e.g.,土壤水分, Kumagai et al., 2004 ; 飽差, Barr et al., 2002 ; Challinor et al., 2004, 雨量（ただし 間接的な効果), Vourlitis et al., 2002 ; PAR, Sumner, 1996）によって時空間的に異なりうる值であり，暖 候期に限っても今回は対象林分に対してやや過剩 な $\alpha$ を設定した可能性がある.さらに, 植生条件に 関連して $a$ の值が変化しうる可能性の例として, 小 松ら（2005）が示した $\alpha に$ 対する針葉樹林の樹高の 影響を基に考えることもできる，小松ら（2005）は 針葉樹林において，樹高が高いほど $ロ$ が小さなる 傾向を示している。それによれば，針葉樹林の平均

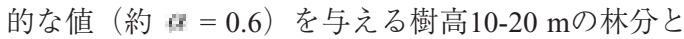
比較すると，樹高 $20 \mathrm{~m}$ 以上の林分の $\alpha$ は抢よそ 0.4 , 樹高 $10 \mathrm{~m}$ 以下の林分の $a$ は执よそ 0.8 とっている. 本稿では, 土壤採取林分の樹高が概ね10-20 mの範 囲であったこと，および入力データセットの制限の ために，針葉樹・広葉樹の違いのみに基づいて針葉 樹の $\alpha$ には一律に0.6を与えた（表一2）。しかしな がら，もし実際にはより樹高の高い林分が広域的 に卓越していた場合， $a$ と蒸散量は比例関係にある ため（式1），本稿における推定蒸散量は過大推定 であったことになる。

第二に，下向き短波放射量を純放射量に換算する パラメータ Rn*/S $\downarrow$ の影響が考えられる. 式1に示す と扔り, $\mathrm{Rn} * / \mathrm{S} \downarrow$ 萵大になると, 蒸散量は過大推 定される。落葉期にはRn*/S $\downarrow$ が小さくなることが 知られているため (小松ら，2005）, 本稿では落葉 性が卓越するカラマツ・ブナ・ミズナラ林にもっと も大きな季節変化を示したデータセットを適用した (表一2)。しかし, 適用したRn*/S レデー夕は常緑樹 を4〜6割含んだ下流部の二次林から得られた実測 值である。これらの值は実際に常落混交林となって いる下流部のコナラ林やシイ・カシ林には適切であ ろうが，より落葉性が卓越する上流部のカラマッ. ブナ・ミズナラ林には冬季の值が過大であったかも しれない。 小松ら（2005）は落葉期にはPriestleyTaylor係数 $\alpha$, 下向き短波放射量 $\mathrm{S} \downarrow$ ともに小さい ため, $\mathrm{Rn} * / \mathrm{S} \downarrow に$ において年一定の值を与えても問題 


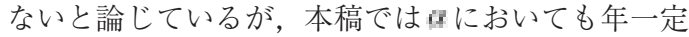

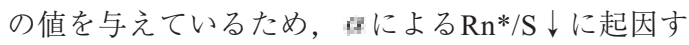
る落葉期の過大推定は補正されないばかりか, $\alpha$ と $\mathrm{Rn} * \mathrm{~S} \downarrow$ の両方で冬季の過大推定を引き起こした可 能性がある。

第三に, 遮断蒸発と同様に雪の影響が考えられる。 融雪に必要な潜熱の60-80％は純放射量によって供 給されており（山崎，1994）, 融雪時とそれ以外を 同一に扱うことは, 融雪時の蒸散を過大推定するこ とになる。

\section{4. 渓流水窒素濃度ポテンシャル}

渓流水窒素濃度ポテンシャルは上流域ほど低い傾 向が認められた（図一4, 表一4). 矢作川流域森林域 から流出する渓流水の実測硝酸濃度に㧍いても, 都 市域から離れた上流域ほど低い傾向が認められてい る (小山ら, 2005). 渓流水窒素濃度ポテンシャル推 定值の平均值（SD）は $1.60 \pm 1.10 \mathrm{mg} \mathrm{N} \cdot \mathrm{L}^{-1}$ であり, この值は小山ら（2005）の実測值の上限 $1.65 \mathrm{mg}$ $\mathrm{N} \cdot \mathrm{L}^{-1}$ に近かった。生態系での一次生産が窒素によっ て制限されている条件では, 森林土壤で生成した硝 酸態窒素の大部分は生物による吸収によって系内に 保持されるため, この結果は驚くべきことではない. しかし, 実測值と推定值の乘離にも関わらず, 両者 に同一の広域的分布パターンが認められたことは, 本稿で用いた広域評価手法に一定の評価を与えるも のと考えられる.

モデルで推定された広域分布パターンは流出窒素 ポテンシャルの広域変動よりはむしろ流出量の広域 変動, すなわち流出量が上流域で大きく下流域で小 さいことに依拠していた。渓流水硝酸濃度に及ぼす 流出量の影響は硝酸濃度の季節的变動の原因として これまでも注目されてきたが (Ohte et al., 2001； Shibata et al., 2001), 硝酸濃度の空間的変動の主因 として示唆されたことは新たな知見といえる。一方, 小山ら（2005）は渓流水硝酸濃度の空間的変動要因 として, 都市域からの距離で異なる窒素降下物量の 影響を示唆している. 窒素降下物量の増大は森林土 壤の硝化活性を促進するとされる(Jefts et al., 2004). しかしながら本稿で推定した流出窒素ポテンシャル の広域分布パターンにおいては下流域で大きい傾向 は認められなかった (表一4)。この傾向は小山ら （2005）が主たる調査対象としたスギ・ヒノキ人工 林に限定しても同じであった。 小山ら（2005）が示 唆する窒素降下物の影響があるとすれば, それは窒
素降下物の増大に伴う様々な影響（Bardgett, 2005) のうち，植物や微生物による生物的吸収プロセスに 掛かるもの, すなわち一次生産者の窒素の生理的必 要量が満たされ, 流入する窒素が森林生態系内に保 持されない窒素飽和 (大類, 1997) に類するものと 予想される。 な招, 小山らの示唆と本稿の結果は矛 盾するものではなく, それぞれの要因の相対的な寄 与度の評価は今後の課題である。

小山・竹中（2006）は中・下流域において, 落葉 広葉樹二次林から流出する溪流水硝酸濃度は低く, スギ・ヒノキ人工林から流出する渓流水硝酸濃度は 高い傾向を認めている。本稿で認められた傾向は小 山・竹中とは逆にコナラ林で高く, スギ・ヒノキ人 工林で低かった (図一4). 本稿で認められたこの傾 向は, IV. 3.で既に述べた植生に依存するパラメー 夕 $ロ$ が樹種間で大きく異なるためである。すなわち コナラ林の流出窒素ポテンシャルはスギ・ヒノキ林 に比べてやや小さいが, 流出量が非常に小さいため に溪流水窒素濃度ポテンシャルが上昇した。小山・ 竹中（2006）は本稿と同様に二次林土壤の硝化速度 が人工林土壤に比して低い傾向を認め，このことが 渓流水硝酸濃度の違いをもたらしている可能性があ るとしている。また一方で, この地域の二次林では 植生の更新が進んでいるため（只木, 2005), 窒素の 需要量が高く，生成した無機態窒素の大半を植物が 吸収・保持している可能性もある。本稿の結果は, 硝化速度の大小だけでは渓流水硝酸濃度の違いを説 明しきれないことを示しており，人工林と二次林の 渓流水硝酸濃度の違いには植物による吸収量が少な からず寄与していると考えられる。

小山・竹中（2006）が示した結果は, 本稿で試作 した渓流水窒素濃度ポテンシャルの広域推定モデル の改良について有益な示唆を与えてくれる. 解析流 域内に存在する林分間で生物による窒素要求量と実 際の供給量のバランスが著しく異なる場合, 渓流水 窒素濃度ポテンシャルと実測窒素濃度の関係が林分 間で異なることになり, 滛流水窒素濃度ポテンシャ ルを実測窒素濃度の指標として用いる前提が成り立 たない. 生物的窒素要求量と実際の供給量のバラン スとは, その系に扔ける窒素の不足の程度を示して いる. 堤（1989）は温帯落葉広葉樹林の斜面上部と 下部で窒素の還元量/吸収量の比が異なり, 系に集 積される窒素量が小さい斜面上部の方が窒素を保持 する率が高いことを示している。また, Ohrui and Mitchell（1997）は高齢林では栄養塩吸収量の減少 
のために流出窒素が増加する傾向を認めている，林 分ごとに異なる窒素要求量の広域デー夕が得られれ ば，本稿で提示した溪流水窒素濃度ポテンシャルと は別個に, 実際の渓流水窒素濃度予測モデルの構築 も可能である.

本稿で推定した流出窒素ポテンシャルおよび溪流 水窒素濃度ポテンシャルは, 生物による吸収や脱窒 を排除した状態での潜在的な窒素可給性の大小とみ なすことができる。言い換えれば，実測の渓流水窒 素濃度が溪流水窒素濃度ポテンシャルに近づくの は，生物による吸収や脱窒が低下したときである。 例えば，伐採等で森林が消失した場合は一時的に， 他には，脱窒サイトとして機能する小流域下部の湿 地が消失した場合には不可逆的に, 渓流水窒素濃度 ポテンシャルで予測される程度の窒素濃度の渓流水 が流出すると考えられる。 Vitousek et al. (1982) は 窒素流出を招きやすい林分に対して, 窒素流出を規 定する一連のプロセスのうち, どの段階が決定的で あるかを明らかにし，適切な森林管理を行うべきだ と提言している。現行モデルは流出窒素ポテンシャ ルおよび渓流水窒素濃度ポテンシャルによって, 多 量ないしは高濃度の硝酸態窒素が流出する可能性の ある林分を予測できる。 また，Ogawa et al. (2006) は脱窒量を規定する小流域の地形と渓流水中の硝酸 態窒素濃度に関係を認めている。これらの成果を組 み合わせることで，森林伐採や流域の土地利用の変 化によって水質への影響が著しい林分を抽出できる 可能性があり, 現行モデルはより高度な森林管理に 寄与しうると考えられる。

\section{V。おわりに}

森林が有する水質形成機能を広域で評価するた め, 森林土壤が有する流出窒素ポテンシャル, 年流 出量, 硝酸態窒素濃度ポテンシャルの三指標を流域 スケールで広域的に推定した。推定には流域スケー ルのGISモデルとPriestry-Taylor式を基礎とする簡易 な蒸発散推定モデルを用いた。その結果, 流出窒素 ポテンシャルと年流出量はともに上流域で大きかっ たが, 流出窒素ポテンシャルを年流出量で除した值 である硝酸態窒素濃度ポテンシャルは下流域で大き くなった。これらの結果は, 流域全体における河川 水質が，上流域から流出する清浄かつ多量の流出水 が中・下流域から流出する高い窒素濃度の流出水を 希釈するプロセスによって形成されることを示唆し
ている，すなわち，ここで対象とした矢作川流域に 掞いても, 渓流水水質を保持・向上させるためには, 上流域の森林からの流出量を確保することととも に, 中・下流域の森林からの流出する溪流水窒素濃 度を減少させることが肝要と考えられる。このため, 広域での水質形成機能の保全管理のためには各流域 の森林を適切に管理する必要があると結論づけら れる。

本稿で提示したモデルは，こうした定性的な理解 に定量的な解釈を与えたものである。このモデルを ベースに新たな知見や改良を加えることで，比較的 広域の流域に拈いて，どの地区の土地利用を重点的 に管理すべきかを考察可能になっていくことが期待 される。

本研究を実施するにあたり, 土壤調査および試料 採取にご協力頂いた愛知県林業センター鈴木祥仁 氏, 名古屋大学稲武フィールド教育支援センター今 泉保次氏, 山口法雄氏抒よび愛知県農林水産部林務 課，森林保全課，および怒田沢県有林管理事務所の 関係各位に厚く御礼申し上げる，土䁃調査方法，分 析手法において, 森林総合研究所 森貞和仁氏, 松 浦陽次郎氏，吉永秀一郎氏，大貫靖浩氏から，また， 熱収支に関する考察において，同所 清水晃氏，玉 井幸治氏から貴重なご教示をいただいた。なお，本 研究は森林総合研究所交付金研究プロジェクト 200003 「森林・農地・水域を通ずる自然循環機能の 高度な利用技術の開発」の一環として行った研究成 果である。

\section{参考文献}

有光一登・中野秀章・森川 靖 (1988): 森と水のサイエンス, 日本 林業技術協会, pp.63-70.

Band LE, Tague CL, Groffman P, Belt K. 2001. Forest ecosystem processes at the watershed scale: hydrological and ecological controls of nitrogen export. Hydrological Processes 15: 20132028. DOI: 10.1002/hyp.253.

Bardgett RD. 2005. The biology of soil. Oxford University Press: Oxford; 242.

Barr AG, Griffis TJ, Black TA, Lee X, Staebler RM, Fuentes JD, Chen Z, Morgenstern K. 2002. Comparing the carbon budgets of boreal and temperate deciduous forest stands. Canadian Journal of Forest Research 32: 813-822. DOI: 10.1139/x01131.

Campbell JL, Hornbeck JW, Mitchell MJ, Adams MB, Castro MS, Driscoll CT, Kahl JS, Kochenderfer JN, Likens GE, Lynch JA, Murdoch PS, Nelson SJ, Shanley JB. 2004. Input-output budgets of inorganic nitrogen for 24 forest watersheds in the northeastern United States: A review, Water Air and Soil Pollution 151: 373-396. DOI: 10.1023/B:WATE.0000009908. 94219.04. 
Challinor AJ, Wheeler TR, Craufurd PQ, Slingo JM, Grimes DIF. 2004. Design and optimisation of a large-area process-based model for annual crops. Agricultural and Forest Meteorology 124: 99-120. DOI: 10.1016/j.agrformet.2004.01.002.

土じょう部 (1976): 林野土壤の分類 (1975), 林業試験場研究報告, 280, pp.1-28.

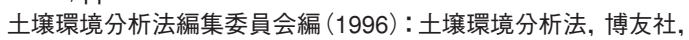
pp.231-254.

土䁃養分測定法委員会編 (1987) : 土壤養分分析法, 養賢堂, pp.205-209.

Grant RF. 2001. Modeling transformations of soil organic carbon and nitrogen at differing scales of complexity. In Modeling Carbon and Nitrogen Dynamics for Soil Management, Shaffer MJ, Hansen S, Ma L (eds). Lewis: New York; 597-630.

Geng QZ, Girard G, Ledoux E. 1996. Modeling of nitrogen cycle and nitrate transfer in regional hydrogeologic systems. Ground water 34: 293-304.

服部重昭(1985): エネルギー収支からみた森林蒸発散, 水利科学, 29, pp.1-23.

服部重昭 (1992): 森林蒸発散の構成成分, 森林水文学 (塚本良則 編), 文英堂出版, pp.78-96.

服部重昭・志水俊夫・荒木 誠・小杉賢一郎・竹内郁雄 (2001) : 森 林の水源かん養機能に関する研究の現状と機能の維持・向上の ための森林整備のあり方 (1) エネルギー収支からみた森林蒸発 散一渴水地域上流森林整備指針策定調査報告一, 水利科学, 45 , pp.1-40.

平井敬三・阪田匡司・森下智陽・高橋正通 (2006) : スギ林土塞の 窒素無機化特性とそれに及ぼす環境変動や施業の影響, 日本森 林学会誌, 88, pp.302-311.

伊藤江利子・小野賢二・今矢明宏・鹿又秀聡 (2004) : 流域スケー ルにおける森林土壤からの窒素流出ポテンシャルの推定, 森林立 地, 46, pp.77-84.

Ito $\mathrm{E}$, Ono K, Araki M. 2007. Variation in nitrogen status indices among forest types within the Yahagi River watershed, central Japan. Bulletin of FFPRI, 6: 1-13.

Jefts S, Fernandez IJ, Rustad LE, Dail DB. 2004. Decadal responses in soil $\mathrm{N}$ dynamics at the Bear Brook Watershed in Maine, USA. Forest Ecology and Management 189: 189-205. DOI: 10.1016/j.foreco.2003.08.011.

環境省: “自然環境保全基礎調査”, 生物多様性情報システム, http://www.biodic.go.jp/kiso/fnd_f.html.（参照: 2006/2/14）

神田 学・森脇 亮・高柳百合子・横山 仁·浜田 崇(1997): 明 治神宮の森の気候緩和機能・大気浄化機能の評価一 (1) 1996年 夏期集中観測一, 天気, 44, pp.713-722.

加藤正樹・小野寺真一・小林政広 (1995): 源頭部森林小流域にお ける土蚺溶液と湧水の硝酸態窒素の動態, 日本森林学会誌, 77 , pp.516-526.

木村園子ドロテア, 岡崎正規, 波多野隆介 (2006): 広域における 窒素循環一評価の現状と今後の展望一, 日本土壌肥料学雑誌, 77, pp.351-359.

国土地理院 (1998): 数值地図ユーザーズガイド(第2版補訂版), 日 本地図センター, 471pp.

国土交通省: (2006): “水文水質データベース”, 水文水質データベ 一ス, http://www1.river.go.jp/.（参照:2006/2/14）

国土交通省河川局: “一級水系の流況 (平成12年)”, 国土交通省 河川局ホームページ, http://www.mlit.go.jp/river/jiten/toukei/ index.html. (参照: 2006/2/14)

小松 光・澤野真治・久米朋宣・橋本昌司 (2005): 森林の特性と 蒸発散量の関係, 日本森林学会誌, 87, pp.170-185.

近藤純正・渡辺 カ•中園 信 (1992) 日本各地の森林蒸発散の熱
収支的評価, 天気, 39, 685-695.

近藤純正 (1994): 水環境の気象学, 朝倉書店, pp.323-338.

小山岳朋・竹中千里 (2006) : 森林からの窒素流出の要因解析, 第 117回日本森林学会大会講演要旨集, $117, \mathrm{pp} .718$.

小山岳朋・竹中千里・山本一清 (2005) : 森林からの窒素流出の広 域的評価, 第116回日本森林学会大会講演要旨集, 116, pp.732.

Kumagai T, Katul GG, Saitoh TM, Sato Y, Manfroi OJ, Morooka T, Ichie T, Kuraji K, Suzuki M, Porporato A. 2004. Water cycling in a Bornean tropical rain forest under current and projected precipitation scenarios. Water Resources Research 40: DOI: 10.1029/2003WR002226.

沓名重明・本庄真・鈴木道代 (1988)：土壤型および樹種の相違に よる窒素の無機化と硝化活性, 日本森林学会誌, 7082, pp.8085.

Ogawa A, Shibata H, Suzuki K, Mitchell MJ, Ikegami Y. 2006. Relationship of topography to surface water chemistry with particular focus on nitrogen and organic carbon solutes within a forested watershed in Hokkaido, Japan. Hydrological Processes 20: 251-265. DOI: 10.1002/hyp.5901.

大類清和 (1997) : 森林生態系での"Nitrogen Saturation". 森林立 地, 39, pp.1-9.

Ohrui K, Mitchell MJ. 1997. Nitrogen saturation in Japanese forested watersheds. Ecological Applications 7: 391-401. DOI: 10.2307/2269507.

Ohte N, Tokuchi N, Shibata H, Tsujimura M, Tanaka T, Mitchell MJ. 2001. Hydrobiogeochemistry of forest ecosystems in Japan: major themes and research issues. Hydrological Processes 15: 1771-1789. DOI: 10.1002/hyp.239.

Shibata H, Kuraji K, Toda H, Sasa K. 2001. Regional comparison of nitrogen export to Japanese forest streams. The Scientific World 1: 572-580. DOI: 10.1100/tsw.2001.371.

清水 晃・宮縁育夫・竹下 幸 (1994): 温暖多雨地域の森林にお ける水文特性 (I) 一熱収支観測による鹿北流域試験地の蒸発散 量変化一, 日本森林学会九州支部研究論文集, 47, pp.225-226.

清水 晃・宮縁育夫・小川泰浩 (1997): 温暖多雨地域の森林にお ける水文特性 (IV) 一流出逓減過程における日変化一, 日本森林 学会九州支部研究論文集, 50, pp.153-154.

Shimizu, A, Shimizu, T, Miyabuchi, Y and Ogawa, Y. 2003. Evapotranspiration and runoff in a forest watershed, western Japan. Hydrological Processes 17: 3125-3139. DOI: 10.1002/ hyp. 1261 .

森林立地調査法編集委員会編 (1999): 森林立地調査法, 博友社, pp.177-181.

Stannard DI. 1993. Comparison of Penman-Monteith, ShuttleworthWallace, and modified Priestley-Taylor evapotranspiration models for wildland vegetation in semiarid rangeland. Water Resources Research 29: 1379-1392. DOI: 10.1029/93WR00333.

Sumner DM. 1996. Evapotranspiration from successional vegetation in a deforested area of the Lake Wales Ridge, Florida. WaterResources Investigations Report, 96-4244. U.S. Geological Survey: Florida; 1-38.

只木良也・河口順子・小松康彦・池上博身 (2000): 豊田市郊外里 山地域における植物の現存量・炭素固定量の推定と水平的分布 標示の試み, 環境科学会誌, 13, pp.421-426.

只木良也 (2005): 里山二次林の遷移と物質生産・その利用一東海 地方を例として一, PREC Study Report, 11, pp.18-23.

高橋順二・長谷部均・白谷栄作・吉永育生 (2000): 河川流域にお ける降雨時流出負荷量の算定に及ぼす影響要因, 水文・水資源 学会誌, 13, pp.216-226.

田村俊和 (1996): 微地形分類と地形発達一谷頭部斜面を中心に一, 
水文地形学一山地の水循環と地形変化の相互作用一(恩田裕一 奥西一夫·飯田智之・辻村真貴編), 古今書院, pp.177-189.

豊田市矢作川研究所 (2006)：“概要”, 豊田市矢作川研究所, http://www.city.toyota.aichi.jp/yahagi/index1.html.

(参照: 2007/4/8)

堤 利夫 (1989): 森林生態学, 朝倉書店, pp.141.

Vitousek PM, Gosz JR, Grier CC, Melillo JM, Reiners WA. 1982. A comparative analysis of potential nitrification and nitrate mobility in forest ecosystems. Ecological Monographs 52: 155-177. DOI: $10.2307 / 1942609$.
Vourlitis GL, Filho NP, Hayashi MMS, Nogueira J de S, Caseiro FT, Campelo JH Jr. 2002. Seasonal variations in the evapotranspiration of a transitional tropical forest of Mato Grosso, Brazil. Water Resources Research 38: 30-31, DOI: 10.1029/2000WR000122.

山崎 剛 (1994): 積雪と大気, 水環境の気象学 (近藤純正編), 朝 倉書店, pp.240-260.

吉田重明・春田泰次・仁王以智夫 (1980): 森林土壤中の窒素の動 態II土壤型の異なる2種の天然林土壤中の窒素の無機化と硝化 活性, 日本森林学会誌, 62, pp.230-233.

（受付：2007年4月23日，受理：2007年10月2日）

\title{
Regional Estimation of Nitrogen Loss Potential from Forest Soils : a Case Study in the Yahagi River Watershed.
}

\author{
Eriko ITO ${ }^{1)}$ Kenji ONO ${ }^{2)}$ Takanori SHIMIZU ${ }^{3)}$ \\ Chisato TAKENAKA $^{4)}$ Shigeaki HATTORI ${ }^{4)}$ Makoto ARAKI ${ }^{1)}$ \\ 1) For. and Forest Prod. Res. Inst \\ (Matsunosato 1, Tsukuba, Ibaraki 305-8687, Japan) \\ 2) Tohoku Res. Ctr., For. and Forest Prod. Res. Inst \\ (Nabeyashiki 92-25, Shimo-Kuriyagawa Morioka, Iwate 020-0123, Japan) \\ 3) Kyushu Res. Ctr., For. and Forest Prod. Res. Inst \\ (Kurokami 4-11-16, Kumamoto 860-0862, Japan) \\ 4) Graduate School of Bioagricultural Sciences, Nagoya University \\ (Furo-cho, Chikusa-ku, Nagoya 464-8601, Japan)
}

We aimed to develop a simple method to predict regional variation in nitrogen loss potentials from forested area in the forested Yahagi River watershed $\left(1,340 \mathrm{~km}^{2}\right)$ in central Japan.

Firstly, we estimated within the watershed variation in nitrogen loss potentials through the following three processes: (1) We investigated the net nitrification rate of surface mineral soils using aerobic laboratory incubation at $30{ }^{\circ} \mathrm{C}$ for 4 weeks ( $\left.\mathrm{mg} \mathrm{N} \cdot \mathrm{kg} \mathrm{soil}^{-1} \cdot 28 \mathrm{~d}^{-1}\right)$; (2) we developed a multiple regression model to predict the net nitrification potential on a per-area basis for surface $(0-5 \mathrm{~cm})$ mineral soils $\left(\mathrm{Mg} \mathrm{N} \cdot \mathrm{km}^{-2}\right)$ from only geographical factors; (3) we predicted the regional variation in the net nitrification potential using available GIS data as explanatory variables.

Secondly, we estimated annual outflow using a combination of a GIS model and a simplified evapotranspiration model. We examined accuracy of the model for estimation of annual outflow by comparing values predicted by the model with values measured at two outflow survey points.

Finally, we estimated nitrate concentration potentials in stream water defined as the net nitrification potential divided by annual discharge $\left(\mathrm{mg} \mathrm{N} \cdot \mathrm{L}^{-1}\right)$ as an index of regional river water quality. We verified that a series of GIS prediction technique could produce the regional trend in measured nitrate concentrations.

Key words : nitrogen leaching, river water quality, regional scale, GIS modeling 